\title{
Literature Review of Cross-border M\&A Performance Test and Path Selection by Chinese Banks
}

\author{
Yan-liang Zhang*, Xiao-ye Zhang \\ School of Finance \\ Shandong University of Finance and Economics \\ Jinan, China
}

\author{
Le-ya Zhang \\ Management School \\ University of Stirling \\ Stirling, United Kingdom
}

\begin{abstract}
In the course of the development of the international banks, cross-border M\&A has become one of the main methods of its realization of international operation. With the opening of China's financial industry on Dec.11th in 2006 , international financial service trade has entered a new era. Faced with the competition of the large commercial banks around the world, China's banks also shift their strategy. In the process of international operation, it is an economic proposition of strong practical significance that how to expand the business area and business scope and improve bank performance through international mergers and acquisitions, thus on the competition of the international finance, we can compete for more financial resources and strengthen the financial strength. This thesis starts from the research on motivation and performance of bank M\&A, and discusses the evaluation method and the path of bank M\&A.
\end{abstract}

Keywords-cross-border M\&A; performance analysis; path selection

\section{INTRODUCTION}

In the past a hundred years, the global banking mergers and acquisitions (hereinafter M\&A) have been surging. Three large-scale M\&A have been formed until now, which have promoted the innovation and development of the theories related to this field. With the acceleration of global economic integration, China's commercial banks have also accelerated their development strategies for internationalization, carried out overseas M\&A business actively, and kept seeking for new profit growth points. In order to play the role of finance further in supporting the economic development, we should combine the national strategy of "One Belt and One Road", the internationalization of RMB and the strategic transformation of China's export-oriented economy. And we need optimize the internationalization route of commercial banks, improve the internationalization efficiency and provide financial support for the export of capacity and capital. Specifically to the banking M\&A, the studies by domestic and overseas scholars mainly include two aspects of motivation and performance, but the research productions of path selection are relatively limited.

This is a phase achievement of China Social Science Fund project "Research on the Performance Test and Path Selection of Cross-border M\&A by Chinese Banks 16BGL045".

\section{RESEARCH ON THE MOTIVATION OF BANK $M \& A$}

The motivation theory of bank M\&A mainly includes the Economies of Scale Theory, Efficient Theory, Transaction Cost Theory, Market Power Theory and the Theory of Diversification Effect. In addition to these theories, Mitehell and Mulherin (1996) put forward the theory of external shock. Brouthers, Hastenburg and Ven (1998) believed that the motives could be divided into three categories: economic motivation, personal motivation and strategic motivation. Weston, Chung and Siu (1998) roughly separated the motives into four categories: strategic drive, ineffective management drive, management interest drive, and equity market-driven [1]. And Berger (1999) divides the motives into two categories of value maximization and non-value maximization. Weston (2002) summed up the motivation of bank M\&A in technological progress, globalization, liberalization of trade and economies of scale and so on [2]. Frohlich and Kavan (2003) insisted that there are four kinds of power to promote bank M\&A activities: effects of economic scale, regional expansion of business, the increment of capital scale and broadness of marketing channels, access to market forces.

The research on the motives of bank M\&A has kept up with the times, and Berger (2003) held that the development of information technology, the relaxation of international financial regulation and the constant cross-border trade had provided good external conditions for the cross-border M\&A [3]. Forecalli Dario, Pozzlo Alberto Franco (2008) concluded that the development of technology, especially information technology, reduces the cost and promotes the development of cross-border M\&A of banks.

Scholars in China have also studied the motives of bank M\&A in depth. It is generally believed that the motives include the following factors: economic globalization, inter-bank international competitiveness, economic situation, channels of international development, diversification of risks, the pursuit of synergy, the realization of mixed operation, escape regulation and so on. Yang De-yong, Gao Wei, Liu Xiao-tong (2016) alleged that internet finance had a serious impact on the traditional business and the efficiency of commercial banks, 
and then promoted commercial banks to carry out M\&A actively.

\section{RESEARCH ON THE PERFORMANCE OF BANK M\&A}

The empirical research on bank M\&A mainly focuses on market value and performance. It is generally believed that the bank with the poor performance was always acquired by the bank with excellent performance, M\&A could generate efficiency to improve earnings, or increase market value for both parties.

Sufian,majid and Haron(2001) completed the study of banking M\&A in Singapore by event study method, and then found that the Singapore Banking Group did not have significant profit improvements after the merger, which could be the result of higher operating costs, but the M\&A surely increased the average overall efficiency[4]. Diaz, Sergio, Azofra (2004) tested the bank performance of the European Union Bank which finished the bank M\&A and Non-bank financial institutions, the results showed that: (1) The efficiency of the Bank increased; (2) The acquisition of nonbank financial institutions could increase European banks' profitability; (3) The increased performance of M\&A would delay at least two years [5].

Koetter (2008) investigated the wave of bank M\&A in Germany in the early 1990s from the angle of cost efficiency and profit efficiency respectively. The study found that: M\&A activities played a significant role in tamping the profitability of the bank, but it was relatively insignificant in the role of cost management [6]. Amir, Diamantoudi and Xue (2008) have also found that M\&A played an important role in the market integration. The enterprises with M\&A possessed higher profitability and operational efficiency than the enterprises without M\&A [7].

Ruth Vander, Vennet(2014) drew a hypothesis based on the analysis of a large number of cases: the business priorities of each industry are different, and the new companies formed after the merger and reorganization could achieve the positive effect of economies of scale, and then enhanced their market competitiveness[8]. Kenneth A. Carow found that merging a bank which has a larger scale than their own banks could expand their original company's performance, enhance the business reputation, and raise the new company's stock price [9].

A study about the performance of bank M\&A in the United States and Europe discovered that large-scale banks could achieve better performance than small-scale banks after M\&A. And the banks which are concentrated in a few geographic areas would achieve better performance than the banks geographically dispersed banks. M\&A always improved the performance of banks significantly (Altunbaş Y, Marqués D, 2008) [10]. Scholars in China also have carried on the extensive research on this question. Zhang Li-zhe (2006) held that the performance of Chinese commercial banks was not obvious because it was subject to the economic situation and scale of the whole financial industry. Ding Hui (2009) conducted a comprehensive study about the M\&A of 79 major banks in the world over the past 1999-2002, and concluded that the improvement of performance within five years after bank M\&A was limited, but there were significant fluctuations in non-performing loans and operating costs. Li Nan (2011) took the M\&A of ICBC as an example, and then he chose the method of data envelopment analysis (DEA) and found that the business performance of China's commercial banks obviously improved after the introduction of strategic investors [11]. Li Shan-min, Zhou Xiao-chun (2012) considered that M\&A which were unrelated to each other completely cannot bring positive benefits to enterprises [12].

Kong Yan-yan, and Shu Jing-hong (2010) made an empirical analysis of 56 large commercial banks ' M\&A in 2001-2003, and concluded that the bank's performance within 5 years after the completion of the M\&A has been improved markedly, but the capital condition has been deteriorating year by year. Yu Guang and Yang Rong (2013) hold that: when the bank M\&A carried out with the transfer of control, shareholders could obtain the amount of excess return. Song Xiu-zhen, Tan Zhong-ming (2014) used the method of EVA to measure the performance of the banks which have completed the M\&A., but they discovered that M\&A not only failed to achieve the expected value, but also reduced the enthusiasm of the staff. Ma Ya-dong (2017) took the M\&A between China Construction Bank and Bank of America as an example, and then he analyzed the performance of short-term stock price and the change to financial index by using the event method and the financial indicators method respectively [13].

For domestic M\&A, higher costs of integration were the key to influence the performance. For cross-border M\&A, the diversification of loan and strategies of credit risk had a positive impact on the performance, but the difference between capital and structure of cost had a negative impact. From the side of the efficiency of bank M\&A, it was found that the activity of M\&A plays an important role in consolidating the profitability of banks and improving the market value of both parties (koetter, 2008; Ma Jun-lu, Man Cheng-xin, 2005; Wen Xin-xiang, 2015) [14], But others have made the opposite research conclusions (Huang De-chun, Xu Yan, 2012). Li Heng and Wu Wei-ku (2013) that the performance of bank M\&A was influenced by the difference of the target region, the background of correlation and the way of merging, and the performance index of M\&A between different strategic groups was significantly different.

\section{RESEARCH ON THE EVALUATION METHOD OF BANK M\&A'S PERFORMANCE}

The existing literature at home and abroad show that the methods of evaluating the performance of bank M\&A mainly include event method and financial indicator method, which are widely used in performance analysis

\section{A. Summary of Research on the Event Method}

The event method was firstly proposed by James Dolly (1933), and was perfected as an empirical method based on events. The event method chooses the stock price of listed companies as the target, analyzes the impact of the event on the listed companies in the short term around the announcement of an event, and investigates whether the company's stock price 
generates the excess rate of return in the window period. Chinese scholars did some basic research, Chen Lu (2005) analyzed the short-term performance of M\&A by event method, and she pointed out that different choice of window period would lead to the different result. The stock price reflected the investors ' expectation to the target company, but it was also influenced by the regulation and transparency of the market.

With the deepening of reform on the financial market, the experience of cross-border M\&A was constantly enriched, which attracted many scholars to study the performance of it. Wu Feng-shuai (2013) took the activity of M\&A between Industrial and Commercial Bank of China and Bank of South Africa as an example, and he combined the event method and the financial Indicators analysis to prove that ICBC has achieved positive growth both in the short term and in the long run. Yu Qin (2013) analyzed the overseas M\&A of China's listed banks in the 2006-2012, then pointed out the existing problems and the situation of development, and concluded that there was different wealth effect for shareholders in the window period.

Through the research studies in China, there is no consensus on whether bank M\&A can bring positive wealth effect to enterprises, and the reason is likely to be the financial crisis in 2008. The bank experienced a financial crisis in the short time after the completion of M\&A, which posed a hindrance to later integration. After 2010, the cross-border M\&A of Chinese banks reached a higher success rates in both short and long term.

\section{B. Summary of Research on the Financial Indicator Method}

The main used method by foreign scholars in analyzing the long-term performance of bank M\&A was the financial indicator method, and the results were basically consistent: M\&A could improve the performance of banks in the long run. This method mainly analyzed the target banks from the capital security, asset liquidity and profitability with financial indicators like capital adequacy ratio, non-performing loan ratio, return on assets, loan-to-deposit ratio, liquidity ratio, etc.

The main used method by Chinese scholars in analyzing the long-term performance of bank M\&A was the financial indicator method too. Li Ping (2002) selected 12 banks which have finished the M\&A in the United States as the sample. Through data analysis, she discovered that there were 6 banks' M\&A achieved a significant increase in profitability, and 5 of these occurred after 1996. So she drew the conclusion: commercial banks' cross-border M\&A entered a new era of development at the end of the 20th century. Li Xin-dan (2005) analyzed the financial index of 103 listed companies in China, and found that M\&A would bring lasting positive effects to listed companies over a period of time. Ma Jun-lu (2008) selected the emerging markets in Asia as a sample and pointed out that the efficiency of domestic M\&A is higher than crossborder, but the latter occupied an important position in the international development strategy. Huang De-chun (2012) carried on the financial analysis to Chinese banks who have completed the overseas M\&A after entering the 21st century. He expressed opinions argued that the effectiveness of introducing the advanced risk prevention from the West was superior than the improvement of profitability. Niu Ting (2012) analyzed the case of Minsheng Bank, and she discussed the development status and the prospects of China's joint-stock commercial banks.

\section{RESEARCH ON THE PATH OF BANK M\&A}

Compared with the research on the motivation and performance of bank $M \& A$, there are fewer studies on the evaluation and the implementation path of bank M\&A. Peng Fu-min (2010) stressed that only the M\&A which were in line with the bank's development strategy after the financial crisis worth implementing. Roehelle L.R. and J.P. Holcomb (2001) held that the growth rate of market, the market scale and the specialty of the banks surely affected the choice of M\&A's routes.

Some scholars agree that in the context of the financial crisis, the depreciation of some high-quality financial assets is beneficial to reduce the cost of M\&A. Gu Peng, Zhang Hongjun(2009) presented a good diagnosis of the significance of accurately grasping the recession and locking the acquired objects in time through the case of HSBC's M\&A. Chinese banks should pay attention to the complement of target banks' business and the diversification of service functions, take into account the mature market and the emerging markets, and build multidimensional management model of cross-border M\&A (Wen Xin-xiang, 2015). But Xu Zhao-yang (2011) emphasized that every market participants needed fully understand the risks and avoid being eager for quick profits in the process of M\&A during the recession [15].

Wang Lei (2007) adopted the strategy of "from small to large, step by step" that was applied to HSBC's cross-border M\&A as an example, he stressed that Chinese banks need to base the development on the localization operations. Wu Lu-lu (2012) reviewed the history of ICBC overseas M\&A, and summed up its strategic path: promote to achieve the goals of internationalization and integration; strengthen the control of risks, keep the costs at an acceptable level, integrate the agencies; adhere to the strategic-oriented M\&A which take the majority shareholding and relative shareholding as the goals. Zhu Ai-ping (2010) expounded the overseas strategy of "overall, fast and steady" for ICBC and the strategy of " break through the key regional firstly" for CMBC, and put forward a series of suggestions on the inferior position of Chinese banking in the market of transnational M\&A. Jia Kai-hui(2017) pointed out that under the guidance of "One Belt and One Road”, ICBC sought the opportunities of overseas investments actively and built 127 branches distributed in 18 countries and regions at the end of 2016. But she also pressed that the risk of overseas $M \& A$ increased as the size of $M \& A$ expanded. Integration is the final procedure of the M\&A. The financial integration, the cultural integration and the integration of human resources are all important guarantee of cross-border M\&A. Meng Chen-xi, Liu Rui-bo and Huang Fang-liang(2012) emphasized that integration was a vital subject to realize the value added after M\&A. 


\section{CONCLUSION}

Domestic and overseas scholars took up some researches on the issue of bank M\&A. However, the foreign researches mainly focused on the performance of M\&A and are mostly based on the empirical analysis. Domestic researches mainly analyzed the current situation and problems of bank M\&A established in the specific situation of China, and they included part of the case analysis and empirical research. In recent years, with the comprehensive strength and international status of China's banking industry rising sharply, cross-border M\&A activities of Chinese banks have become increasingly active, and have become an important force in the international M\&A market. At the same time, domestic scholars still lack research on the performance and the path of banks' cross-border M\&A, we need to conduct a more in-depth and systematic study.

\section{ACKNOWLEDGMENT}

This is a phase achievement of China Social Science Fund project "Research on the Performance Test and Path Selection of Cross-border M\&A by Chinese Banks 16BGL045".

\section{REFERENCES}

[1] Weston, J. K., Chung and J. Siu, "Takeovers, Restructuring, and Corporate Governance (2nd Edition),” Prentice-Hall, 1998.

[2] Weston, J. F, “The Exxon-Mobil Merger: An Archetype,” Journal of Applied Finance, Vol. 12, 2002, pp.121-169.

[3] Berger A N, Dai Q, Ongena S, et al. To what extent will the banking industry be globalized? A study of bank nationality and reach in 20 European nations. Journal of Banking \& Finance, 2003, 27(3), pp.383415.
[4] Sufian, F., M. A. Majid and R. Haron, "Efficiency and Bank Merger in Singapore: A Joint Estimation of Non-Parametric, Parametric and Financial Ratios Analysis,” Munich Personal RePEc Archive Paper, 2008, No. 12129.

[5] Diaz, Sergio and Azofra, Determinants of Premiums Paid in European Banking Merger and Acquisitions. Unpublished paper, 2004.

[6] Koetter, M, “An Assessment of Bank Merger Success in Germany,” German Economic Review, Vol. 9, 2008, pp.232-264.

[7] Amir, R., E. Diamantoudi, and L. Xue, “Merger Performance under Uncertain Efficiency Gains,” International Journal of Industrial Organization, Vol. 27, 2008, pp. 264-273.

[8] Ruth Vander,Vennet, "The Effect of Mergers and Acquisition mainly on the Efficiency and the Institutions," Journal of Banking \& Finance, 2012(20), pp.1531-1558.

[9] Kenneth.A.Carow, "Challenging Barriers between Banking and insurance,” Journal of Banking \&Finance, 2015(25), pp.2553-2580.

[10] Altunbaş Y, Marqués D, Mergers and acquisitions and bank performance in Europe: The role of strategic similarities. Journal of Economics and Business, 2008, 60(3), pp. 204-222.

[11] Diao Cheng-chao, "Literature Review of M\&A Performance of Chinese Commercial Bank,” Journal of Financial Development Research, 2014(7), pp.12-16. (In Chinese).

[12] Li Shan-min and Zhou Xiao-chun, "Influential Factor Analysis of Merger Value Production,” Managerial World, 2013(5), pp.134-143. (In Chinese).

[13] Ma Ya-dong, Research on cross-border merger performance of Chinese state-controlled banks: A case study of China Construction Bank's acquisition of BofA Asia, Shanghai International Studies University, 2017. (In Chinese).

[14] Wen Xin-xiang and Wang Jia-jia, “Internatioanlization Path Choice of Chinese-funded Banks after Financial Crisis,” Financial Forum, 2015(7). (In Chinese).

[15] Xu Zhao-yang and Yang Qing, “Mergers and Acquisitions Strategies and Performance Analysis of JPMorgan Chase,” New Finance, 2011(3), pp.20-24. (In Chinese). 